\title{
Aktualisasi Nalar Zari'ah dalam Mengantisipasi Kejahatan melalui Financial Technology
}

\author{
H. Firman Muhammad Arif 1 * \\ ${ }^{1}$ Pascasarjana IAIN Palopo. Jl. Agatis Balandai, Kota Palopo, Sulawesi Selatan, Indonesia. \\ * Korespondensi Penulis. E-mail: firmanarif@iainpalopo.ac.id
}

\begin{abstract}
Abstrak
Jasa keuangan berbasis teknologi adalah inovasi zaman yang menyederhanakan proses dan memudahkan. Perkembangan yang baru seiring dengan munculnya kejahatan baru yang justru meresahkan masyarakat. Formula hukum Islam yang bersumber dari wahyu baik secara tekstual, maknawiyah dan spirit dijadikan media untuk memitigasi maraknya kerusakan. Normalisasi keadaan buruk hanya bisa direalisasikan dengan memasifkan aktualisasi nalar zari'ah yang sarat dengan mengoptimalkan maslahat atau memaksimalkan maslahat. Tulisan ini bermaksud menjadikan nalar zar'iah sebagai pisau bedah dan analisis yang awalnya normatif menjadi aktual di ranah publik sebab dengan adanya nalar zari'ah inilah sehingga beberapa perkara termasuk maraknya fintech ilegal dibedah, ditelaah, direkonstruksi dan diminimalisir supaya keadaan menjadi kondusif atau kejahatan dapat terminimalisir. Idealitas nalar zari'ah dalam formula penggalian hukum Islam yang telah dirumuskan ulama salaf dinilai masih relevan dengan perkembangan zaman yang selalu sarat dengan dinamika dan perubahan. Nalar zari'ah dengan dua variannya, sadd (menutup, menghalangi) dan fathu al zariah (membuka media, wasilah) dalam tulisan ini memberikan penilaian bahwa sadd al zari'ah lebih diprioritaskan daripada fathu al zari'ah. Perkembangan baru selalu memunculkan aksi kejahatan baru sehingga diperlukan media pendukung lainnya untuk menghilangkan atau meminimalisir tindakan kejahatan dari maraknya fintech ilegal yang menjerat banyaknya korban dan mendongkrak keuntungan sepihak daripada mendorong kemandirian masyarakat.
\end{abstract}

Kata Kunci: epistemologi sadd al zari'ah, realitas fintech, perlindungan hukum

\section{Actualization of Zari'ah's Reason in Anticipating Crimes through Financial Technology}

\begin{abstract}
Technology-based financial services are an age-old innovation that simplifies processes and makes it easy. The new development is in line with the emergence of new crimes which actually disturb society. The formula of Islamic law sourced from revelation both textually, meaningfully and spirit is used as a media to mitigate the rampant damage. Normalization of bad conditions can only be realized by ensuring the actualization of zari'ah reason which is loaded with optimizing benefits or maximizing benefits. This paper intends to make zar'iah reasoning as a scalpel and initially normative analysis becomes actual in the public sphere because with the existence of zari'ah reasoning so that several cases including the rise of illegal fintechs are dissected, analyzed, reconstructed and minimized so that conditions can be conducive or crime can be minimized. The ideality of zari'ah in the formula for extracting Islamic law which has been formulated by the salaf cleric is considered still relevant to the times that are always laden with dynamics and change. Reason zari'ah with its two variants, sadd (closing, blocking) and fathu al zariah (opening the media, be careful) in this paper gives an assessment that sadd al zari'ah is prioritized over fathu al zari'ah. New developments always lead to new crime so that other supporting media are needed to eliminate or minimize crime from the rise of illegal finteches which ensnare victims and boost unilateral profits rather than encouraging community independence.
\end{abstract}

Keywords: epistemology sadd al zari'ah, reality fintech, legal protection 


\section{PENDAHULUAN}

Revolusi industri ke-4 datang seiring perkembangan teknologi yang semakin pesat termasuk robotic dan kecerdasan buatan. Pergeseran industri telah terjadi di berbagai negara dan menjadi keniscayaan di Indonesia yang berpenduduk Islam secara mayoritas. ${ }^{1}$ Eksistensi Islam sebagai rahmatan li al alamin (kesejahteraan semesta) yang diembannya tentu tidak akan tinggal diam menyikapi kemajuan tersebut. Islam sering kali dikontraskan antara idealitas ajarannya dengan realitas umatnya. ${ }^{2}$ Dinamika umat Islam dari masa ke masa sarat dengan kegiatan pendikotomian antara dimensi sakral dengan dimensi profan ajarannya; teosentris dengan antroposentris kandungannya, bahkan antara aspek religiositasnya (kesalehan, pengabdian terhadap agama) yang paling asasi dengan perkembangan peradaban bangsa yang paling terkini. ${ }^{3}$

Perkembangan dalam bidang apapun tidak lepas dari dinamika umat yang selalu sarat dengan perubahan ke arah yang lebih baik dan modern. Ketertinggalan adalah stagnasi yang tidak menguntungkan dan perkembangan adalah dinamika yang sarat dengan kemanfaatan. Arus globalisasi yang semakin deras, nyaris tak terbendung dan bahkan merambah ke berbagai dimensi. Pesatnya teknologi informasi menuntut manusia untuk mendayagunakan teknologi dalam proses pembelajaran. ${ }^{4}$

Akselerasi teknologi informasi acap kali memposisikan agama apapun di dunia ini dalam posisi yang diperdebatkan. ${ }^{5}$ Menanamkan nilai-nilai kebaikan di tengah revolusi industri memungkinkan terjadinya perubahan metode pembelajaran, pola komunikasi dan aspek finansial dalam keluarga yang patut jadi perhatian. ${ }^{6}$ Agama samawi atau bukan samawi tertuntut untuk menggiring umatnya ke jalan yang seirama dengan ajarannya termasuk Islam dengan populasinya yang dinilai signifikan di dunia sekitar 1,8 miliar terhitung Maret 2019. Indonesia sebagai negara dengan populasi muslim terbanyak tahun 2019 berjumlah 227.226 .404 jiwa. $^{7}$

Ajaran Islam bersumber dari wahyu yang sarat dengan nilai kebenaran mutlak dan absolut namun diiringi dengan pemahaman terhadap teks wahyu yang bersifat nisbi dan relatif. Teks wahyu dalam Alquran berupa dalil-dalil qat'i yang konstan dan immutable disikapi dengan menerimanya secara mutlak dan tanpa melakukan adaptasi dengan perubahan. Adapun selebihnya berupa aturanaturan juz'i dan dzanni sebagai lahan ijtihadi. ${ }^{8}$ Segmen tersebut dinilai sangat rekat dengan sentuhan fenomena sosial dan kemasyarakatan.

Kesibukan dalam perkara fikih, pengalaman dan pengamalan keagamaan yang cenderung esoteris (bersifat khusus), tidak boleh menafikan apalagi memarginalkan fungsi akal. ${ }^{9}$ Pesan profetik dalam sumber hukum Islam senantiasa bersikap ramah dan membawa keteraturan hidup bagi semua manusia melalui ajaran Alquran dan sabda Rasulullah saw. Dalam kajian sosiologis dan filosofis, nilai-nilai agama bersinergi antara manusia, Tuhan dan lingkungannya (sosial, politik, budaya dan ranah teknologi). ${ }^{10}$

${ }^{1}$ Ngakan Timur Antara \& Sonny Iskandar, Hot Economy, Strategi Revolusi Industri 4.0, keterangan ahli sebagai Wakil Ketua Umum KADIN, Sekretaris Jenderal APINDO dan Ketua Umum Himpunan Kawasan Industri Indonesia, diakses via beritasatu.tv dan dipublikasikan 6 April 2018.

${ }^{2}$ Lihat, Asmawi, Dimensi-dimensi Syari'ah Dari Teologi, Hukum, Akhlaq Sampai Sejarah Pemikiran (Tulungagung: STAIN Tulungagung Press, 2013), h. 9.

${ }^{3}$ Lihat, Abu Yasid, Islam Moderat (Jakarta: Erlangga, 2018), h. 12

${ }^{4}$ Muhammad Zain, Era Baru Pendidikan Tinggi, Belajar dari Hong Kong, Orasi Ilmiah Pembukaan Kuliah Akademik 2013-2014 STAIN Palopo, 9 September 2013, h. 6.

${ }^{5}$ Lihat, Abdu al Karim Muhammad al Mudarris, 'Ulama'una fi Khidmati al Ilmi wa al Din (Cet. I; Maroko: t.t., 1983), h. 3

${ }^{6}$ Muhammad Zain, Era Baru Pendidikan Tinggi, Belajar dari Hong Kong, h. 7

${ }^{7}$ Caksono, Jumlah Populasi Muslim Dunia, dirilis dari website Media Indonesia pada tanggal 12 September 2019.

${ }^{8}$ Lihat, Qasim Mathar, Membuka Jendela Langit (Makassar: Galesong Group, 2017), h. 17

${ }^{9}$ Lihat, Azaki Khoiruddin, "Sains Islam Berbasis Nalar Ayat-Ayat Semesta”, Jurnal At Ta`dib Volume 12 Nomor 1 Tahun 2017, h. 196.

${ }^{10}$ Muhammad Akmaluddin, "Pesan Profetik Lingkungan dalam Hadis", Jurnal Penelitian IAIN Pekalongan, Volume 14 Nomor 2 Tahun 2017, h. 216. 
Perangkat teknologi yang merambah ke berbagai dimensi kehidupan termasuk penggalangan dana oleh gerakan-gerakan sosial secara online atau crowdfunding dinilai semakin semarak. ${ }^{11}$ Perkembangan crowdfunding hanya satu dari sekian jenis pemanfaatan layanan keuangan berbasis teknologi atau diistilahkan sebagai financial technology (Fintech). Teknologi keuangan atau fintech merupakan sesuatu baru, sejalan dengan perubahan gaya hidup dan pola transaksi keuangan di masyarakat.

Penyedia dan pengguna layanan fintech seperti pembayaran, investasi ritel, perencanaan keuangan, pembiayaan termasuk penggalangan dana dan lainnya dinilai sebagai komunitas yang up to date. Layanan tersebut dikembangkan perusahaan rintisan atau start up yang semakin hari semakin menjamur dengan produknya yang juga beragam. Kemajuan teknologi yang sarat dengan kemudahan namun tida luput juga adanya aksi yang memudah-mudahkan.

Daya saing yang mendongkrak perekonomian dan memudahkan layanan terutama dalam menjangkau wilayah-wilayah dengan keterbatasan layanan keuangan justru menjadi celah kejahatan, mengesampingkan kenyamanan dan mengekrdilkan aspek keamanan. Islam memainkan peranan penting dalam sejarah kemajuan umat manusia dan pencapaian kemajuan dalam bidang apapun di era sekarang termasuk teknologi yang bukan untuk diperdebatkan karena kontribusi peradaban Islam telah memberikan pengaruh terhadap hasil yang dicapai. ${ }^{12}$

Penetrasi layanan keuangan berbasis teknologi oleh pelaku industri diakomodir dalam ajaran Islam dengan kaidahnya yaitu tetap menjaga nilai-nilai klasik namun tetap menerima segala sesuatu yang dinilai baru dan memberikan kemaslahatan. ${ }^{13}$ Keberadaan fintech dapat diimplementasikan pada industri bank syariah sehingga memudahkan dan mendekatkan pelaku bisnis khususnya yang berkenaan dengan akses produk-produk layanan dan pengajuan pembiayaan tanpa harus datang ke kantornya secara langsung. ${ }^{14}$

Teknologi berpotensi menghadirkan maslahat namun bisa juga menampilkan muslihatnya dengan memperdaya korban, mengeruk keuntungan dan menghalalkan segala cara. Beragam jenis fintech yang berkembang pesat dan salah satunya Peer to Peer Lending (P2P lending) berfokus pada layanan pinjam dan meminjam secara online. Informasi terendusnya perkara kejahatan Peer to Peer Lending dari Otoritas Jasa Keuangan, terungkap sebanyak 227 yang belum terdaftar dan berdiri secara ilegal dinilai telah merugikan pemakainya, marak dengan penyalahgunaan, pencucian uang dan bahkan digunakan sebagai pendanaan gerakan terorisme. ${ }^{15}$

\section{METODE}

Penelitian ini bersifat deskriptif analitik yaitu memaparkan berbagai data yang tercantum dengan cara melakukan observasi di berbagai sumber media seperti televisi, surat kabar, berita online, media youtube dan penelusuran situs-situs pemerintahan yang dinilai minim dari manipulasi data dan ditindaklanjuti dengan analisa untuk mendapatkan kesimpulan yang benar dan akurat. Pendekatan kualitatif digunakan dalam penelitian ini dengan teknik atau metode studi fenomena yang marak di masyarakat.

Metode berarti cara atau jalan yang harus dilalui untuk mencapai sesuatu. Metode adalah langkah-langkah praktis dan sistematis yang ada dalam ilmu-ilmu tertentu yang tidak perlu lagi

\footnotetext{
${ }^{11}$ Sondang Martha Samosir et.all., Menjamin Keamanan FinTech, Jakarta: Majalah Otoritas Jasa Keuangan Edukasi Konsumen Edisi Desember 2017, h. 2-3.

${ }^{12}$ Lihat, Musthafa Husni as Siba'i, Min Rawaa'i Hadaratina, diterjemahkan oleh Abdullah Zakiy al Kaaf dengan judul: Khazanah Peradaban Islam (Cet. I; Bandung: Pustaka Setia, 2002), h. 40-41

${ }^{13}$ Lihat, Djazuli, Kaidah-kaidah Fikih, Kaidah-kaidah Hukum Islam dalam Menyelesaikan Masalahmasalah yang Praktis (Cet. III; Jakarta: Kencana Prenada Media, 2010), h. 91.

${ }^{14}$ Lihat, Inayah Aulia Rahma et. all., "Peran Fintech dalam Meningkatkan Keuangan Inklusif pada UMKM di Indonesia", Masharif al Syariah Jurnal Ekonomi dan Perbanan Syariah Vol. III No. 1 Tahun 2018, h. $1-24$

${ }^{15}$ Fernika Sari, Hati-hati, Fintech Ilegal Terus Berkeliaran Cari Korban, diakses via kontan.co.id pada tanggal 21 September 2019.
} 
dipertanyakan karena sudah bersifat aplikatif. ${ }^{16}$ Penelitian yang dilakukan dalam tulisan ini adalah mencari, menjelajah, dan menemukan makna kembali secara berulang-ulang yang bersifat ex-post facto, yaitu untuk membedah, mengangkat dan merekonstruksi fenomena yang sudah ada. Dalam istilah teknis hukum Islam, upaya menemukan hukum dinamakan istinbath. ${ }^{17}$

Metode penelitian hukum dalam tulisan ini lebih terkesan normatif daripada empiris sehingga tidak banyak menyapa disiplin lain yang empiris. ${ }^{18}$ Istilah sadd al zari'ah cukup banyak diperbincangkan karena memiliki keterkaitan dengan lingkup pembahasan maslahah yang selanjutnya dielaborasi dalam maqasid al syari'ah berikut lima hal yang harus dijaga yaitu agama, jiwa, akal, keturunan dan harta. ${ }^{19}$

Nalar zari'ah menjelma sebagai proses istidlal (pengambilan dan penggalian) hukum dalam wilayah usul fiqh. Jadi usul fiqh adalah disiplin ilmu yang memproduksi fikih dari sumbernya dengan seperangkat metodologi. Tegasnya, usul fiqh ialah perangkat yang membahas tentang bagaimana cara menemukan dan mengeluarkan hukum dari sumbernya. ${ }^{20}$ Fenomena perkembangan teknologi dalam layanan keuangan telah menggiring perubahan pola hidup yang berkembang di masyarakat dengan kecenderungan mengedepankan efektifitas, efisiensi dan ekonomis.

Fintech didominasi beberapa perusahaan rintisan atau start up namun di sisi lain inovasi finansial yang dikemas dengan sentuhan teknologi modern menjadi celah munculnya berbagai kasus kejahatan. ${ }^{21}$ Kejahatan dikemas dengan sentuhan teknologi dinilai sebagai trik dan trend dalam melakukan kriminal yang menghalalkan segala cara seperti pencemaran nama baik, tindakan pengancaman asusila, pornografi atau prostitusi online melalui media elektronik, tindakan pencucian uang dan pendanaan aksi terorisme. ${ }^{22}$

Tulisan ini bermuatan kajian teoritis yang berkenaan dengan upaya preventif atau dalam kajian usul fiqh sebagai ilmu yang membahas metodologi perumusan hukum Islam yang diviralkan dengan istilah sadd al zari'ah (mencegah media). Persoalan baru dan kontemporer membutuhkan jawaban fikih atas kasus-kasus kontemporer yang belum tercover dalam kitab-kitab fikih klasik.

\section{HASIL DAN PEMBAHASAN}

\section{Dinamika Perkembangan FinTech}

Merangseknya teknologi ke publik dibuktikan dengan realitas menjamurnya smartphone di tengah masyarakat sehingga segala hal bergerak ke arah perubahan termasuk layanan keuangan. Perkembangan tersebut di seluruh dunia tidak bisa dipisahkan dari kemajuan teknologi dan gaya hidup modern. Jasa keuangan yang terintegrasi dengan teknologi mengubah model bisnis keuangan konvensional dengan mengganti dan menyederhanakan proses. ${ }^{23}$ Alih status dari rumitnya proses ke arah penyederhanaan adalah akibat hasil gabungan antara keuangan dan teknologi. Model muamalah

\footnotetext{
${ }^{16}$ Muhyar Fanani, Metode Studi Islam Aplikasi Sosiologi Pengetahuan sebagai Cara Pandang (Yogyakarta: Pustaka Pelajar, 2008), h. ix

${ }^{17}$ Sofyan A.P Kau, Metode Penelitian Hukum Islam Penuntun Praktis untuk Penulisan Skripsi dan Tesis (Cet. I; Gorontalo: Sultan Amai Press IAIN Gorontalo, 2009), h. 3-4

${ }^{18}$ Lihat, Widodo Dwi Putro \& Herlambang P Wiratraman, "Penelitian Hukum, antara Normatif dan Empiris”, Digest Epistema Isu Hukun dan Keadilan Eko-Sosial Volume 5/2015, h. 5

${ }^{19}$ Lihat, 'Abdul al Wahab al Khallaf, Ilmu Usul al Fiqh (Cet. XII; al Qahirah: Dar al Ilmi, 1398 H), h. 84

${ }^{20}$ Lihat, Manna' al Qatthan, Tarikh Tasyri' al Islamiy, al Tasyri' wa al Fiqh (Riyadh: Maktabah al Ma'arif, 1422 H), h. 183. Lihat, Sofyan A.P Kau, Metode Penelitian Hukum Islam Penuntun Praktis untuk Penulisan Skripsi dan Tesis, h. 14

${ }^{21}$ Lihat, Agus Tiar Saleng, Tantangan dan Peluang Revolusi Industri 4.0, Opini Harian Fajar tanggal 24 Juli 2019, h. 6.

${ }^{22}$ Wimboh Santoso, Jerat Maut Pinjaman Online, diakses dari cnnindonesia.com dan Channel CNN Indonesia di Trans Vision pada 31 Mei 2016.

${ }^{23}$ Karania Dalharmasaputro, Menakar Masa Depan Financial Technology, sebagai CEO Baraksa dalam liputan ekonomi finansial CNN Indonesia pada tanggal 25 September 2016.
} 
konvensional menjadi moderat dimana mekanisme pembayaran dengan bertatap muka dan membayar sejumlah uang tunai dialihkan menjadi transaksi jarak jauh hanya hitungan beberapa detik saja. ${ }^{24}$

Kemunculan fintech didominasi oleh generasi pengguna teknologi informasi dengan tuntutan serba cepat. Fintech memobilisasi kemandirian masyarakat dan kemudahan untuk mengakses layanan keuangan bahkan berkembang menjadi industri yang mendukung sejumlah sektor-sektor dalam perekononomian seperti pertanian dan finansial. ${ }^{25}$ Dengan kata lain, fintech membantu transaksi jual beli dan sistem pembayaran semakin efisien dan ekonomis namun tetap efektif.

Teknologi keuangan mendorong tumbuhnya bisnis daring (online) dan perdagangan secara elektronik (e-commerce) ${ }^{26}$ Generasi milenial terkesan masif dengan beraktifitas depan pesona internet termasuk jual beli dan pembayaran daring. Perubahan gaya hidup modern memicu munculnya model bisnis gaya baru berbasis teknologi finansial yaitu perusahaan rintisan atau startup berbasis teknologi. ${ }^{27}$ Beberapa kategori fintech yang sudah merambah di Indonesia adalah pinjaman, asuransi, pembayaran, internet banking, donasi dan manajemen keuangan. ${ }^{28}$

Indonesia berada di posisi kelima dunia sebagai pencetak startup setelah Amerika Serikat, India, Inggris, dan Kanada. Tercatat 2074 startup dengan beragam bidang, seperti pembiayaan, jual beli, peer to peer lending (pinjam meminjam) dan lainnya. ${ }^{29}$ Merebaknya startup dilirik menjadi penyedia teknologi pendukung seperti amazon.com dimana menyasar pengusaha muda di bidang digital dengan tawaran berbagai layanan komputerisasi berkualitas tinggi bagi pengusaha startup di Indonesia. ${ }^{30}$

Startup teknologi menjadi favorit di kalangan pemuda untuk memulai usaha sehingga evolusi digital dari pergerakan barang dan jasa menawarkan keuntungan besar meskipun dalam kenyataannya menjalankan bisnis startup tidak mudah dan diperlukan kegiatan edukatif bagi pelaku industri startup seperti event lokal startup Fest 2017 Jakarta. ${ }^{31}$ MOKA selaku startup di Indonesia turut berkontribusi dalam mengedukasi pelaku usaha kecil menengah (UKM) dengan kegiatan berbasis edukasi teknologi digital. Gerakan nasional 1000 startup pada 29 Agustus 2019 di Baruga Pettarani Makassar. ${ }^{32}$

Berikut beberapa startup di Indonesia dengan peringkatnya di dunia dan akrab di masyarakat seperti Bukalapak peringkat 17, blibli.com peringkat 24, Taveloka peringkat 35, Zalora peringkat 44, dan Zenius Education peringkat $94 .{ }^{33}$ Fakta lainnya seperti potensi fintech di Indonesia seperti yang disajikan pada Tabel 1.

Tabel 1. Potensi FinTech

\begin{tabular}{cc}
\hline Potensi FinTech & Keterangan \\
\hline 49 Juta Usaha Kecil Menengah & Belum 'Bankable' \\
$36 \%$ Rakyat Indonesia & Belum mempunyai rekening bank
\end{tabular}

\footnotetext{
${ }^{24}$ Agus D.W Martowardojo, Financial Technology Office Bank Indonesia, sambutan sebagai Gubernur BI saat peresmian Kantor Fintech BI 14 November 2016.

${ }^{25}$ Desi Anwar, Membangun Perekonomian Digital di Indonesia, dalam wawancara bersama Pendiri TANIHUB \& KOINWORKS di Insight CNN Indonesia dipublikasikan tanggal 9 Desember 2016.

${ }^{26}$ Benedicto Haryono \& Ivan Ari Sustiawan, Membangun Perekonomian Digital di Indonesia, keterangan sebagai Pendiri TANIHUB \& KOINWORKS di Insight CNN Indonesia dipublikasikan tanggal 9 Desember 2016.

${ }^{27}$ Lihat, Iswi Hariyanti \& Cita Yustisia Serfiyanti, "Perlindungan Hukum dan Penyelesaian Sengketa Bisnis Jasa PM-TEKFIN", Jurnal Legislasi Indonesia Volume 14 No. 03 September 2017, h. 333-346

${ }^{28}$ Otoritas Jasa Keuangan, OJK membagi bisnis Fintech berdasarkan layanan dan pelakunya.

${ }^{29}$ Topindonesia, Indonesia Startup Ranking, diakses via https://www.startupranking.com/top/indonesia pada tanggal 21 September 2019.

${ }^{30}$ Cindy Mutia Annur, Dorong 1000 Startup Kominfo Siapkan Berbagai Program Inovasi, sambutan saat pertemuan The $1^{\text {st }}$ Next Indonesia Unicorn International Summt di Bali 9 Mei 2018 dan diakses via katadata.co.id pada tanggal 21 September 2019.

${ }^{31}$ Hendrikus Passagi, Membangun Perekonomian Digital di Indonesia, keterangan sebagai Dirjen Pengawasan Fintech OJK, dipublikasikan 4 November 2017 di CNN Indonesia TV.

${ }^{32}$ Putri Salsabila, Dukung UKM Kreatif, MOKA Luncurkan Forum Edukasi ACOM, diakses via ekonomi.bisnis.com pada tanggal 12 Agustus 2019.

${ }^{33}$ Izak Jenie, Dewan Pengurus Asosiasi Fintech Indonesia dengan Startup Ranking
} 
EKSPOSE: Jurnal Penelitian Hukum dan Pendidikan, 18 (2), Desember 2019 - 853

H. Firman Muhammad Arif

\begin{tabular}{cc}
\hline Potensi FinTech & Keterangan \\
\hline 88 Juta & Telah menggunakan internet \\
325 Juta & Sudah terkoneksi dengan Mobile \\
\hline
\end{tabular}

Potensi Fintech tersebut menjelma ibarat lahan bisnis yang menggiurkan dengan jumlah penduduk Indonesia diperkirakan kurang lebih 300 juta jiwa ${ }^{34}$ dengan jumlah pengguna internet tahun 2013 tercatat 83,7 juta, tahun 2016 berjumlah 103 juta pengguna internet, dan tahun 2019 berjumlah 133,5 juta. Catatan pengguna internet disinyalir telah banyak berkecimpung dalam transaksi ecommerce dengan datanya disajikan pada Tabel $2 .{ }^{35}$

Tabel 2. Transaksi E-Commerce di Indonesia

\begin{tabular}{cc}
\hline Tahun & $\begin{array}{c}\text { Jumlah } \\
\text { (Milliar Dollar AS) }\end{array}$ \\
\hline 2011 & 0,56 \\
2012 & 1,04 \\
2013 & 1,79 \\
2014 & 2,6 \\
2015 & 3,56 \\
2016 & 4,49 \\
\hline
\end{tabular}

Angka transaksi dan jumlah penduduk Indonesia menuntut perlunya peningkatan kapasitas sumber daya manusia karena startup memungkinkan untuk gulung tikar jika tidak melakukan pembenahan. Berikut kategori dan prosentase startup yang gulung tikar ${ }^{36}$ dengan alasan yang disajikan pada Tabel 3.

Tabel 3. Kategori dan Persentase Startup Gulung Tikar

\begin{tabular}{cc}
\hline Alasan & $\begin{array}{c}\text { Persentase } \\
(\%)\end{array}$ \\
\hline Tak dibutuhkan pasar & 42 \\
Kehabisan uang & 28 \\
Tim yang dinilai tidak pas & 23 \\
Kalah saing & 19 \\
Harga dan bebabn biaya & 18 \\
\hline
\end{tabular}

Pada umumnya yang membuat startup bangkrut adalah legal fee, pajak, bunga dan pendanaan serta penyusutan. ${ }^{37}$ Pengembangan sistem pendidikan diperlukan untuk perkembangan dan kemajuan startup. Pelaku ekonomi digital tertuntut dan terpaksa gesit beradaptasi di beragam industri digital. Primadona yang akrab dengan financial technology berkembang seiring dengan e-commerce dan penawaran beraneka jasa yang serba online.

Industri keuangan digital memerlukan kebijakan OJK dan BI (mengatur dan perlindungan hukum) serta dukungan infrastruktur keuangan yang biasanya menjadi momok utama permasalahan. Jika infrastruktur pendataan kuat maka Fintech akan berkembang kuat dan perbankan juga akan menikmati produk fintech. ${ }^{38}$ Selama 2017, nilai transaksi fintech mencapai US\$ 18,65 Miliar dengan jumlah 184 perusahaan fintech di Indonesia.

Keuntungan dari fintech untuk konsumen antara lain: layanan yang lebih baik, pilihan lebih baik dan keterjangkauan harga. Manfaatnya bagi pemakai fintech (pedagang produk dan penyedia jasa) antara lain: menyederhanakan rantai transaksi, menekan biaya modal dan operasional serta

${ }^{34}$ Kailash Raghuwanshi, Pakar Startup dalam wawancara saat acara Property of CNBC Indonesia.

${ }^{35}$ Cindy Mutia Annur, Survey Asosiasi Penyelenggara Jasa Internet; Penetrasi Pengguna Internet di Indonesia Capai 64,8\%, diakses dari https://katadata.co.id/ pada tanggal 20 September 2019.

${ }^{36}$ Aline Wiratmaja, Dilema Startup Bakar Uang, dibahas dalam Program Profit CNBC Indonesia pada 14 Maret 2019.

${ }^{37}$ Nurhaida, Peluang Fintech di Indonesia, sebagai Wakil Ketua Otoritas Jasa Keuangan OJK dalam acara Tech News CNN Indonesia.

${ }^{38}$ Ajisatria Suleiman, Masa Depan Industri Keuangan Digital, sebagai Direktur Eksekutif Asosiasi Fintech Indonesia dalam acara Property of CNN Indonesia. 
membekukan alur informasi. Sedang manfaat untuk negara antara lain; peningkatan kecepatan perputaran keuangan sehingga meningkatkan keuangan ekonomi masyarakat dan mendorong strategi keuangan nasional. ${ }^{39}$

Industri jasa keuangan dengan inovasinya sekarang ini dinilai sangat singnifikan dan sejalan dengan pesatnya teknologi digital. Menurut Financial Stability Board (FSB), fintech adalah inovasi finansial berbasis teknologi yang menghasilkan model bisnis, aplikasi, proses atau produk baru dengan efek material terkait pada pasar keuangan, institusi, dan penyedia layanan keuangan. Sedangkan menurut The National Digital Research Centre (NDRC), fintech merupakan innovation in financial services(inovasi pada sektor finansial).

Pernyataan tersebut mempertegas bahwa prinsip fintech adalah a fusion between technology and financial services. Penggunaan handpone sebagai layanan mobile banking dan investasi ibarat perpaduan teknologi dengan sistem keuangan guna memberikan layanan keuangan yang lebih mudah diakses. Fintech dengan kemudahannya mampu mengakses produk-produk, mempermudah transaksi dan meningkatkan literasi keuangan. Modalku sebagai salah satu startup mempertemukan pemberi dan pencari modal usaha. Peluang Fintech perlu diimbangi dengan melakukan edukasi masyarakat karena dinilai rendah dan terbatas di kota besar saja. ${ }^{40}$

Penetrasi bank yang pencapaiannya 50 juta rumah tangga di tanah air hanya menyasar $30 \%$ masyarakat Indonesia yang memiliki akses terhadap bank. Rendahnya penetrasi bank tersebut menimbulkan sejumlah persoalan seperti sulitnya masyarakat di wilayah pedesaan yang menempatkan fasilitas pembiayaan ataupun kredit. Namun di sisi lain penetrasi telepon seluler sudah mencapai angka 281 juta pengguna dengan membuka peluang baru sehingga fintech dimunculkan sebagai solusi alternatif. $^{41}$

Pesatnya industri fintech memicu maraknya pendirian berbagai startup berbasis teknologi dengan jenis jasanya, seperti peer to peer (P2P) lending (peminjaman), crowdfunding, payment gateway (alat pembayaran), dan manajemen investasi. Beberapa jenis usaha tersebut maka layanan P2P lending dalam masyarakat dinilai rawan dan beresiko disalahgunakan. ${ }^{42}$

Kegemaran berbelanja secara online memicu munculnya aplikasi sistem pembayaran online yang dinilai lebih mudah dan praktis dibandingkan dengan sistem pembayaran dengan uang, cek, bilyet giro, kartu kredit dan uang elektronik. Pengguna internet juga bisa mengakses utang/pinjaman secara online melalui laman perusahaan jasa "pinjam meminjam berbasis teknologi finansial". ${ }^{43}$

Perkembangan fintech terkesan belum sepenuhnya seirama lajunya dengan negara lain seperti China, Hong Kong dan India. Berdasarkan data oleh perusahaan konsultan manajemen bisnis McKinsey \& Company dalam laporan terbarunya berjudul Digital Banking in Indonesia: Building Loyalty and Generating Growth, tingkat penetrasi penggunaan layanan keuangan melalui fintech di Indonesia masih sekitar 5\%. Angka tersebut tersebut jauh lebih rendah dibandingkan dengan negara China dengan presentasi 67\%, Hong Kong 57\% dan India 39\%. Meskipun demikian, fintech di Indonesia tetap mempunyai potensi besar untuk lebih berkembang ke depannya karena berdasarkan survei tahun 2017, pertumbuhan digitalisasi di Indonesia menjadi salah yang tercepat di dunia, bahkan mengalahkan China dan Brazil. ${ }^{44}$

Penetrasi internet di Indonesia menurut CNN Indonesia tahun 2016, baru menyasar sekitar 20\% dan celah bisnis fintech seperti populasi yang belum menggunakan bank sekitar $81 \%$ dan belum ada

\footnotetext{
${ }^{39}$ Bank Indonesia, Edukasi, diakses dari https://www.bi.go.id/id pada tanggal 22 September 2019.

${ }^{40}$ Nurhaida, Peluang Fintech di Indonesia, sebagai Wakil Ketua Otoritas Jasa Keuangan OJK dalam acara Tech News CNN Indonesia.

${ }^{41}$ Karania, Menakar Masa Depan Financial Technology, keterangan sebagai CEO Bareska di CNN Indonesia dipublikasikan 23 September 2016.

${ }^{42}$ Hera F. Haryn, Masa Depan Industri Keuangan, diakses dari cnnindonesia.com dan Channel CNN Indonesia di Trans Vision pada 31 Mei 2016.

${ }^{43}$ Lihat, Iswi Hariyanti \& Cita Yustisia Serfiyanti, "Perlindungan Hukum dan Penyelesaian Sengketa Bisnis Jasa PM-TEKFIN", h. 334.

${ }^{44}$ Ahmad Zainuddin, Proyeksi 2019 Menyambut Kejutan-kejutan Dunia Fintech, diakses via https://tirto.id pada tanggal 10 September 2019.
} 
regulasi spesifik. ${ }^{45}$ Menurut data Otoritas Jasa Keuangan sampai bulan Januari 2019, penyaluran pinjaman fintech mencapai Rp 25,92 triliun. Jumlah penyaluran tersebut naik 14,36\% dari awal tahun 2018 yang tercatat senilai Rp 22,67 triliun. Angka ini masih tergolong kecil, karena berdasarkan penelitian OJK pada tahun 2016, terdapat kesenjangan pendanaan di Indonesia sebesar Rp 989 triliun per tahunnya. Kesenjangan tersebut disebabkan kebutuhan pendanaan sebesar Rp 1.649 triliun tak mampu dipenuhi oleh lembaga keuangan yang hanya memiliki total aliran dana Rp 660 triliun.

Oleh karena itu, potensi industri fintech dipastikan berkembang apalagi didukung dengan maraknya kebutuhan pendanaan dari masyarakat yang belum sepenuhnya dipenuhi bank. Beberapa perusahaan masih dalam proses perizinan sehingga jumlah perusahaan fintech ini juga akan terus bertambah. ${ }^{46}$ Peluang tersebut perlu diimbangi dengan melakukan edukasi masyarakat sebagal terobosan mencerdaskan dan mendongkrak literasi keuangan. ${ }^{47}$ Realitas perkembangan fintech yang cukup potensial tentu tidak luput dari adanya modus kejahatan. Akal bulus dari penyedia jasa teknologi keuangan akan mengusik kenyaman konsumen, penipuan, rentenir online dan penyalahgunaan data pribadi sehingga perlu disoroti dengan perhatian ekstra karena dimana ada perkembangan baru maka disitu ada modus kejahatan baru. ${ }^{48}$

Modus penipuan dalam teknologi finansial berkenaan dengan beberapa hal seperti; penawaran pinjaman atas nama lembaga tertentu, meminta uang atas nama biaya adminitrasi, masif menghubungi calon peminjam, dan adanya paksaan permintaan informasi kartu kredit. Ciri-ciri ilegal yang patut diperhatikan sebagai berikut; Bunga denda sangat tinggi, penyalahgunaan data pengguna, penagihan pinjaman di luar jam kerja, dan intimidasi melalui data peminjam. Kontroversi pinjaman uang online menyasar maraknya korban dengan jumlah pinjaman yang variatif, bunga per hari atau per bulan, jaminan pinjaman yang melibatkan rumah dan mobil bahkan biasanya ditambahkan biaya lain-lain seperrti administrasi, percepatan pelunasan, perpanjangan dan biaya debt collector. ${ }^{49}$

Adapun fintech yang dinilai ilegal sebagai berikut; tidak terdaftar di lembaga pemerintah (OJK, BI dan Kemeninfo), penyamaran kantor pengelola, tidak punya email resmi dan syarat atau proses yang terkesan mudah. Berbeda dengan fintech yang legal dengan ciri-cirinya seperti bunga yang tidak mencekik, pemeriksaan riwayat kredit, layanan yang mudah dihubungi, terdaftar di OJK, mempunyai alamat jelas, situs dan emailnya yang resmi dan mekanisme yang transparan.

Otoritas Jasa Keuangan sebagai lembaga pemerintah secara masif melakukan pengawasan penindakan akibat maraknya tindak kejahatan finansial secara online akibat cepatnya kemajuan teknologi di industri keuangan digital yang tidak bisa dianggap remeh. Hal tersebut membuat sektor keuangan melakukan inovasi di industri perbankan digital, pasalnya saat ini marak pinjaman online yang ilegal atau belum terdaftar di OJK.

Rilis dari Waspada Investasi ditemukan 144 entitas yang melakukan kegiatan bidang financial technology dan telah dihentikan. ${ }^{50}$ Terhitung 6 September 2019, Satgas Waspada Investasi menemukan 123 fintech lending ilegal dan 30 usaha gadai yang tidak terdaftar di Otoritas Jasa Keuangan. ${ }^{51}$ Sampai saat ini, berdasarkan data statistik Otoritas Jasa Keuangan per tanggal 1 Februari 2019, terdapat 99 perusahaan fintech lending yang telah terdaftar dan berizin di Otoritas Jasa Keuangan (OJK) dan 54 fintech sistem pembayaran yang terdaftar di Bank Indonesia (BI).

\footnotetext{
${ }^{45}$ Hera F. Haryn, Masa Depan Industri Keuangan, diakses dari cnnindonesia.com dan Channel CNN Indonesia di Trans Vision pada 31 Mei 2016.

${ }^{46}$ Abdul Rasyid, Sekilas Perkembangan Fintech di Indonesia, artikel diakses dari https://businesslaw.binus.ac.id pada tanggal 12 September 2019.

${ }^{47}$ Nurhaida, Peluang Fintech di Indonesia, sebagai Wakil Ketua Otoritas Jasa Keuangan OJK dalam acara Tech News CNN Indonesia.

${ }^{48}$ Tongam L. Tobing, Daftar Nama 143 Fintech Ilegal, sebagai Satgas Waspada Investigasi dan diakses via cnbcIndonesia.com.

${ }^{49}$ Hera F. Haryn, Masa Depan Industri Keuangan, diakses dari cnnindonesia.com dan Channel CNN Indonesia di Trans Vision pada 31 Mei 2016.

${ }^{50}$ Tongam L. Tobing, Waspada Fintech Ilegal, sebagai Ketua Satgas Waspada Investasi dalam wawancara eksklusif TV One yang dipublikasi pada 18 Juli 2019.

${ }^{51}$ Tongam L. Tobing, Daftar 123 Fintech Ilegal Temuan Baru Satgas Waspada Investasi, diakses https://www.cnbcindonesia.com/ pada tanggal 30 September 2019.
} 
Perkembangan akhir rilis OJK hingga 31 Mei 2019, fintech lending yang terdaftar dan berizin adalah 113 perusahaan dan yang tidak berizin atau ilegal sebanyak 1087 perusahaan. ${ }^{52}$

\section{Epistemologi Sadd Al Zari'ah}

Epistemologi zari'ah dalam pembahasan ini bermaksud mengungkapkan dasar dan batas pengetahuan yang terdapat dalam literatur hukum Islam. ${ }^{53}$ Pengertian zari'ah secara bahasa sebagai berikut:

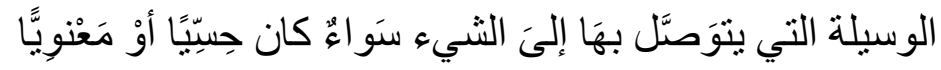

"Artinya: Jalan yang membawa kepada sesuatu, hissi (abstrak) atau ma'nawi, baik atau buruk"

Arti bahasa diatas bermuatan netral tanpa ada indikasi penilaian kepada hasil perbuatan. Pengertian netral tersebut diadopsi oleh Ibnu al Qayyim sebagaimana yang dikutip dalam bukunya ${ }^{54}$ ke dalam rumusan definisi zari'ah, yaitu:

"Artinya: apa-apa yang menjadi perantara dan jalan kepada sesuatu"

$$
\text { ما كان وسيلة وَطرِيًْا إلى الثَيْهَ }
$$

Selanjutnya Badran mendefinisikan zari'ah tanpa netralitas didalamnya sebagai berikut:

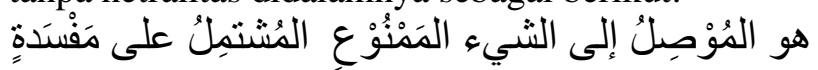

“Artinya: apa yang menyampaikan kepada sesuatu yang terlarang dan bermuatan kerusakan"

Penempatannya dalam bahasan disesuaikan dengan tujuannya, sedang kata zari'ah yang didahului dengan lafal saddu سدّ berarti "menutup" yang dimaksudkan menutup akses terjadinya kerusakan. ${ }^{55}$ Kata sadd yang terpisah dari kata zari'ah, dikemas secara teks dalam Alquran dalam beberapa ayat, seperti:

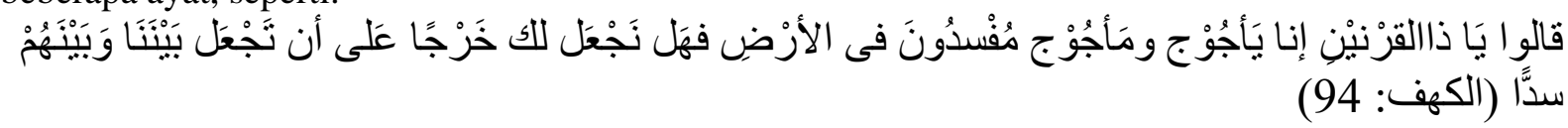

“Artinya: Mereka berkata: "Hai Dzulkarnain, sesungguhnya Ya,juj dan Ma'juj itu orang-orang yang membuat kerusakan di muka bumi maka dapatkah kami memberika sesuatu pembayaran kepadamu supaya kamu membuat dinding antara kami dan mereka"

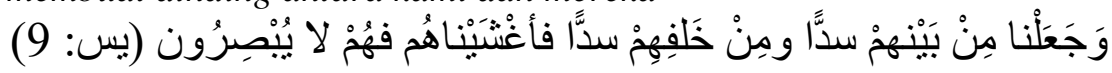

"Artinya: dan kami adakan di hadapan mereka dinding dan di belakang mereka dinding (pula), dan kami tutup (mata) mereka sehingga mereka tidak dapat melihat"

Kedua ayat di atas berkekuatan tetap dan menegaskan makna sadd sebagai penghalang, dinding, benteng atau sesuatu yang digunakan untuk membendung dan menutup adanya celah yang berakibat pada masuknya sesuatu yang tidak dikehendaki. Kecenderungan Wahbah Zuhali berpandangan ke definisi netral mengenai sadd zari'ah karena keberpihakannya tentang definisi tersebut sama dengan yang diungkapkan Ibnu al Qayyim. ${ }^{56}$

Beberapa ulama ada yang memeperselisihkan sadd al zari'ah sebagai dalil yang bisa dijadikan pegangan dengan kategori dalam kemandiriannya. Imam Ibnu al Qayyim menukil dan menilainya bisa menjadi dalil yang otonom dengan mengungkap adanya 99 dalil yang melegitimasi sadd al zari'ah. ${ }^{57}$ Demikian pula dengan Imam al Syatibi yang sepakat dengan beberapa ulama salaf mengenai orisinalitas sadd al zari'ah. Perbedaan hanya terjadi pada tahqiq manat sadd al zari'ah tersebut dalam sebagian yang dinilai bagian-bagiannya. ${ }^{58}$

\footnotetext{
${ }^{52}$ Wimboh Santoso, Jumlah Fintech Ilegal Semakin Semarak, Kepala Otoritas Jasa Keuangan dalam Kabar Pasar TV One, Juli 2019.

${ }^{53}$ Lihat, Badan Pengembangan dan Pembinaan Bahasa, Kamus Besar Bahasa Indonesia Daring (Jakarta: Kemdikbud, 2016), diakses via online dari kbbi.kemdikbud.go.id

${ }^{54}$ Amir Syarifuddin, Ushul Fiqh II (Cet. V; Jakarta: Logos Wacana Ilmu, 2009), h. 424

${ }^{55}$ Muhazzab Abu Ahmad, Nahwa Fiqh Wa'in Sadd al Zari'ah, diaskes dari https://saaid.net/aldawah/191.htm pada tanggal 4 Oktober 2019.

${ }^{56}$ Amir Syarifuddin, Ushul Fiqh II, h. 424

${ }^{57}$ Lihat, Imam Ibnu al Qayyim, I'lam al Muwaqqi'in III, h. 177-255

${ }^{58}$ Syatibi, al Muwafaqat III h. 193
} 
Dalam kajian usul fiqh, zari'ah adalah istilah klasik namun masih relevan untuk diviralkan dalam menyikapi berbagai perkara yang tidak ada muatan tekstual dan kontekstual dalam Alquran dan Hadis Nabi karena relasi sadd zari'ah menempel ketat dengan konsep maslahat, terutama yang berkenaan dengan spiritnya.

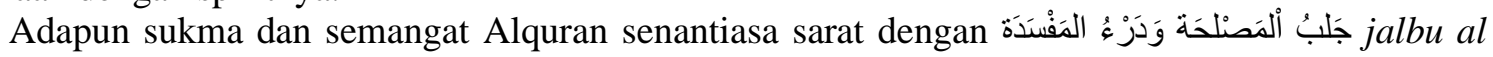
maslahah wa dar'u al mafsadah (merealisasikan sesuatu atau yang dinilai baik dan menghilangkan, meminimalisir hal-hal yang buruk atau segala sesuatu yang berpotensi merusak dan membahayakan). ${ }^{59}$ Izzudin bin 'Abdu al Salam di dalam kitabnya qawa'id al ahkam fi masalih al anam sebagaimana yang dikutip Misbahuddin, bahwa seluruh syari'at adalah maslahat. Kerja manusia ada yang membawa maslahat dan ada pula yang menyebabkan mafsadah. Maslahat maupun mafsadah ada yang terindikasi dengan kepentingan duniawi sekaligus ukhrawi. ${ }^{60}$

Spirit Alquran tersebut menginspirasi, mengilhami, membisikkan dan menggerakkan hati mukallaf untuk melakukan sesuatu yang seirama dengan maslahat yang menjadi spirit Alquran. Setiap hukum yang disyariatkan Allah SWT bertujuan mewujudkan maslahat. Syari'at menetapkan berbagai metode berdasarkan kaidah-kaidahnya yang dijadikan pedoman bagi mujtahid dalam melakukan istinbat hukum. Pedoman tersebut mengisyaratkan mujtahid melakukan ijtihad dan memberikan tuntunan dalam upaya merumuskan produk hukum yang bersejalan dengan maqasid al syari'ah. ${ }^{61}$ Penggalian hukum Islam dengan pendekatan maqasid al syari'ah dikenal dengan istilah ijtihad maqasidi dan telah digagas oleh al Syatibi dalam karyanya al Muwafaqat. ${ }^{62}$

Penalaran filosofis dalam hukum Islam memiliki corak yang khas dengan tujuan menangkap nilai-nilai maslahat yang terkandung dalam teks wahyu dengan mempertimbangkan realitas sosial yang berkembang dalam masyarakat, termasuk dalam hal ini perkembangan teknologi keuangan. Corak penalaran filosofis dibangun dari rasionalitas dengan tetap menjadikan nas (teks wahyu) sebagai dasar dalam memahami maksud-maksud yang terkandung didalamnya maupun adanya makna lain yang terdapat di balik nas tersebut. ${ }^{63}$

Corak penalaran filosofis hukum Islam adalah ta'lili dan istislahi. Ta'lili berasal dari kata illat, diartikan nama bagi sesuatu yang menyebabkan berubahnya keadaan sesuatu yang lain dengan keberadaannya. Singkat kata, formula untuk menyingkap motif hukum atau sifat yang jelas, terukur dan memiliki relevansi dalam penetapan hukum. ${ }^{64}$ Berbeda dengan istislahi, berarti mencari kemaslahatan dalam suatu masalah yang tidak ada nasnya dan konsensus ulama atau maslahat yang tidak dijelaskan dalam syariat.

Kehujjahan istislahi adalah cara yang diakui syariat untuk menyimpulkan hukum yang tidak ada dalam nas dan ijma'. Begitupun dengan al Thufi bermazhab Hanbali bahwa istislahi adalah dalil pokok dalam masalah muamalah yang disimpulkan pada hukum yang disyariatkan guna mewujudkan manfaat dan menolak bahaya. Singkat kata dari pernyataan tersebut dirumuskan secara jelas, singkat dan padat makna bahwa dimana terdapat maslahat maka di situ terdapat syariat Allah. ${ }^{65}$

Ijtihad hukum hanya bisa dijalani dengan melakukan nalar yang bersesuaian dengan teks, makna dan semangat Alquran. Salah satu metode perumusan atau corak penalaran filosofis dengan kategori istislahi adalah zari'ah dan untuk membantu memahaminya maka perlu dielaborasi secara

${ }^{59}$ Mukhsin Nyak Umar, Kaidah Fiqhiyyah dan Pembaharuan Hukum Islam (Cet. II; Banda Aceh: Yayasan WDC Banda Aceh, 2017), h. 31. Lihat, Djazuli, Kaidah-kaidah Fikih, Kaidah-kaidah Hukum Islam dalam Menyelesaikan Masalah-masalah yang Praktis, h. 27.

${ }^{60}$ Misbahuddin, Ushul Fiqh; Studi Kaidah Lughawiyah, Kedudukan Hukum, Prioritas dan Pengembangannya (Makassar: Alauddin Press, 2014), h. 233

${ }^{61}$ Mukhsin Nyak Umar, Kaidah Fiqhiyyah dan Pembaharuan Hukum Islam, h. vii

${ }^{62}$ A. Halil Thahir, Ijtihad Maqasidi, Rekonstruksi Hukum Islam Berbasis Interkoneksitas Maslahah (Cet. I; Yogyakarta: LKiS Printing cemerlang, 2015), h. 81.

${ }^{63}$ Achmad Musyahid Idrus, Perkembangan Penalaran Filosofis dalam Hukum Islam (Cet. I; Makassar: Alauddin University Press, 2013), h. 133.

${ }^{64}$ Achmad Musyahid Idrus, Perkembangan Penalaran Filosofis dalam Hukum Islam, h. 134.

${ }^{65}$ Wahab Khallaf, Masadir al Tasyri' al Islamiy Ma la Nassa Fihi, diterjemahkan oleh Abubakar dan Anwar Rasyidi dengan judul: Sumber-sumber Hukum Islam (Cet. I; Bandung: Risalah, 1984), h. 124. Lihat, Achmad Musyahid Idrus, Perkembangan Penalaran Filosofis dalam Hukum Islam, 158-159. 
tepat dan akurat. Secara etimologi, berarti wasilah dalam pengertian terminologinya adalah jalan yang menyampaikan atau membawa kepada keharusan atau kehalalan. ${ }^{66}$

Dalam arti lain, nalar zari'ah adalah sarana dan jalan menuju kepada sesuatu. ${ }^{67}$ Definisi tersebut sesuai dengan yang disampaikan Abdul Karim Zaidan yang menegaskan secara bahasa sebagai sarana dan jalan kepada sesuatu, baik yang baik maupun yang buruk, perkataan atau ucapan. ${ }^{68}$ Nalar zari'ah dalam hukum Islam dibagi menjadi dua yaitu fathu (membuka) dan sadd (menutup, menghalangi). Nalar sadd al zari'ah adalah pengkhususan terhadap sesuatu yang menggiring seseorang kepada yang dilarang dan berkonotasi buruk dan membahayakan. ${ }^{69}$ Pendapat lainnya ada yang mengemukakan bahwa sadd al zari'ah adalah menutup dan menghalangi sesuatu. ${ }^{70}$

Jika dalam menghadapi suatu perkara dan perkara tersebut menjelma sebagai sarana yang berpotensi timbulnya sebuah kerusakan dan membahayakan maka sarana atau wasilah tersebut harus ditutup dan dicegah sehingga pantas disebut dengan sadd al zari'ah. Berbeda dengan fathu al zari'ah yang diartikan sebagai suatu sarana yang menggiring kepada kemaslahatan. ${ }^{71}$ Makna sadd al zari'ah memungkinkan dan menemukan tempatnya untuk dijadikan sebagai perangkat hukum untuk dikembangkan dalam dinamika kehidupan umat manusia sebab keberadaan sadd al zari'ah menggiring mujtahid melakukan elaborasi dan upaya hukum untuk menetapkan larangan terhadap satu kasus hukum yang pada dasarnya dianggap mubah. ${ }^{72}$ Larangan yang terdapat didalamnya dimaksudkan untuk menghindari perbuatan atau tindakan lain yang dilarang. ${ }^{73}$

Imam Malik menjadikan sadd al zari'ah sebagai landasan dalam menetapkan hukum. Menurutnya, semua jalan atau sebab yang menuju kepada yang haram atau terlarang, hukumnya haram atau terlarang. Salah satu kaidahnya: النهي على الثيء يدل على المفسدة artinya: larangan terhadap sesuatu menunjukkan adanya kerusakan didalamnya. Semua jalan atau sebab yang menuju kepada yang halal, halal pula hukumnya. ${ }^{74}$ Muhammad Abu Zahrah dan al Fasi dengan mengutip pendapat al Qurtubi bahwa varian zari'ah ada 4 kategori, yaitu:

a. Zari'ah secara pasti dinilai untuk menggiring ke mafsadah (sesuatu yang merusak dan berpotensi merusak atau dinilai merusak);

b. Zari'ah yang jarang membawa maslahah. Pembudidayaan anggur dengan adanya kemungkinan diproses untuk menjadi minuman keras, namun hal tersebut dinilai jarang;

c. Zari'ah yang dinilai adanya dugaan kuat akan menggiring kepada mafsadah. Penjualan anggur kepada orang lain atau perusahaan dengan izin usaha memproduksi minuman keras dan kategori tersebut dilarang;

d. Zari'ah yang kerap dan sering menggiring munculnya mafsadah namun kekhawatiran tersebut dengan dasar asumsi biasa. Jual beli secara kredit, yang dinilai akan menggiring terjadinya kerusakan terutama bagi debitur. Kategori ini diperselisihkan kalangan ulama. ${ }^{75}$

Berbagai makna tersebut menunjukkan bahwa sadd al zari'ah dinilai relevan sebagai metode yang secara langsung bertautan dengan memelihara kemaslahatan dan menghindarkan diri dari

${ }^{66}$ Muhammad Abu Zahrah, Usul Fiqh (Cairo: Dar al Fikr al Arabiy, t.th), h. 288

${ }^{67}$ Muhammad bin al Hasan al Hujwi al Tsa'labi al Fasi, al Fikr al Sami fi Tarikh al Fiqhi al Islami (Cet. I; Beirut: Dar al Kutub al Ilmiyyah, 1995), h. 162

${ }^{68}$ Abdul Karim Zaidan, al Wajiz fi Usul al Fiqh (Beirut: Muassasah al Risalah, 1987), h. 245

${ }^{69}$ Nasrun Haroen, Ushul Fiqh I (Jakarta: Logos Wacana Ilmu, 1997), h. 160.

${ }^{70}$ Nasrun Rusli, Konsep Ijtihad al Syaukani (Jakarta: Logos Wacana Ilmu, 1999), h. 35

${ }^{71}$ Moh. Mahrus, Aplikasi al Zari'ah dan al Hilah dalam Perspektif Hukum Islam, diakses medianeliti.com pada tanggal 12 September 2019.

${ }^{72}$ Fathurrahman Azhari, Qawa'id Fiqhiyyah Muamalah (Cet. I; Banjarmasin: Lembaga Pemberdayaan Kualitas Umat, 2015), h. 2

${ }^{73}$ Lihat, Muhazzab Abu Ahmad, Nahwa Fiqhi Wa'in Sadd al Zari'ah, diakses dari https://saaid.net/aldawah/191.htm pada tanggal 4 Oktober 2019. Lihat pula, Fathurrahman Djamil, Filsafat Hukum Islam (Jakarta: Logos Wacana Ilmu, 1997), h. 143

${ }^{74}$ H. B. Syafuri, "Epistemologi Hukum Fatwa KUI Kabupaten Lebak tentang Berboncengan dengan Selain Muhrim", Jurnal Al Ahkam Volume XVI No. 2 Juli 2016, h. 217

${ }^{75}$ Muhammad bin al Hasan al Hujwi al Tsa'labi al Fasi, al Fikr al Sami fi Tarikh al Fiqhi al Islami, h. 62 
mafsadah. ${ }^{76}$ Perbuatan yang awalnya dinilai mubah, namun menjadi haram atau terlarang karena dijadikan sebagai sarana kepada perbuatan yang diharamkan.

Keberadaan sadd al zari'ah secara umum berpeluang menuntun terwujudnya sebuah ekspektasi yang tidak tercerabut dari realitas sosial dan kemampuan hukum Islam berdialog dengan kebutuhan masyarakat. Produk pemikiran ulama dalam hukum Islam (fikih) tetap memiliki akar tradisi ke masa lampau tetapi relevansinya dengan masa kini semakin bersejalan. Hal tersebut membuktikan bahwa warisan ulama klasik tempo dulu, masih bisa dipakai untuk menjawab soal-soal masa kini. Generasi muda Islam tertuntun dan tertuntut untuk memperlakukan fikih secara kreatif. ${ }^{77}$

\section{Aktualisasi Sadd Al Zari'ah}

Keuangan berbasis teknologi semakin bertambah pesat dimana kemajuan tersebut mengubah semua pekerjaan menjadi lebih mudah. ${ }^{78}$ Fintech tidak lagi dengan uang tunai namun dengan transaksi via gawai seperti layanan pembayaran dengan dompet digital. ${ }^{79}$ Tak hanya itu, pengajuan kredit atau pinjaman tidak luput dari penetrasi teknologi dan cukup dengan mendayagunakan aplikasi. ${ }^{80}$

Sumber ajaran Islam dari Alquran dan Hadis Nabi tidak menafikan kemajuan selama memberikan maslahat dan bukan menunjukkan adanya muslihat. Kemajuan dalam dinamika kehidupan adalah mutlak harus terjadi karena manusia adalah makhluk sosial dan berakal yang senantiasa berusaha menuntun hidupnya ke arah yang menjanjikan, baik dengan mendongkrak status sosial, politik, pendapatan hidup, mengubah gaya hidup atau mendongkrak perubahan dengan memastikan temuan-temuan baru yang membawa kemaslahatan manusia.

Keberadaan fintech tidak luput dari sorotan hukum Islam karena Alquran adalah wilayah ijtihadi yang maha luas dan perkara agama yang paling prinsipil dan fundamental tidak boleh tergerus oleh perkembangan zaman. Berbeda halnya dengan fintech yang masuk dalam ranah furu'iyyah sebagai wilayah pemikiran dan ijtihadi. ${ }^{81}$ Fintech adalah kreatifitas zaman yang bebas nilai sehingga penggunanya tertuntun dan tertuntut untuk menggunakan perangkat tersebut dengan alasan efektifitas dan efisiensi.

Secara ideal, penemuan dan kreatifitas manusia semestinya menjadi perangkat yang bersejalan dengan ajaran agama dan bukannya menggerus nilai Islam. Penetrasi teknologi dalam keuangan sepatutnya mencerahkan, memudahkan, berdaya efisiensi, efektifitas dan bukan malah memarginalkan atau merusak tatanan kehidupan. Perkembangan apapun termasuk teknologi menjadi celah yang dapat digunakan untuk mengeksploitasi pihak lain dan salah satu jenis fintech yang rentan terjadi manipulasi adalah peer to peer lending atau pinjaman online. ${ }^{82}$

Perbuatan pokok atau pelengkap yang dilakukan seorang muslim telah diatur oleh syariat dan termasuk dalam ranah al ahkam al khamsah (lima kategori hukum dalam Islam) ${ }^{83}$ Keberadaan fintech

\footnotetext{
${ }^{76}$ Lihat, Amir Syarifuddin, Ushul Fiqh Jilid II (Cet. V; Jakarta: Kencana Prenada Media, 2009) h. 424

${ }^{77}$ Lihat, Abdul Djalil et. all., Fiqh Rakyat Pertautan Fiqh dengan Kekuasaan (Cet. II; Yogyakarta: LKiS Pelangi Aksara Yogyakarta, 2011), h. xxii-xxiii.

${ }^{78}$ Lihat, Teguh Ariwibowo, Jerat Pinjaman Online, diakses dari metrotv.com dan dipublikasikan dalam NSI Metro TV pada tanggal 6 Juni 2016.

${ }^{79}$ Data Bank Indonesia, terdapat 38 dompet digital atau e-wallet yang mendapatkan lisensi resmi. Tahun 2018 transaksi e-wallet di Indonesia sudah mencapai angka USD 1,5 miliar bahakn diprediksi akan meningkat menjadi USD 25 miliar pada tahun 2023. Lihat, Anisatul Umah, Merger OVO-DANA, Siasat Grab Jegal Gojek, liputan Closing Bell CNBC Indonesia dipublikasikan 12 September 2019 atau diakses via cnbc.indonesia.com/tech pada tanggal 24 September 2019.

${ }^{80}$ Wimboh Santoso, Jerat Maut Pinjaman Online, diakses dari cnnindonesia.com dan Channel CNN Indonesia di Trans Vision pada 31 Mei 2016.

${ }^{81}$ M. Qasim Mathar, Alquran Wilayah Ijtihadi yang Maha Luas, disarikan dari Opini Harian Pagi Fajar 21 September 2019, h. 6.

${ }^{82}$ Lihat, Eka Budiyanti, “Upaya Mengatasi Layanan Pinjaman Online Ilegal”, Jakarta: Pusat Penelitian Badan Keahlian DPR RI Bidang Ekonomi dan Kajian Publik Info Singkat Kajian Singkat terhadap Isu Aktual dan Strategis Vol. XI No. 04/II/Puslit/Februari 2019, h. 19.

${ }^{83}$ Hifdhatul Munawaroh, "Sadd al Zari'ah dan Aplikasinya pada Permasalahan Fikih Kontemporer", Jurnal Ijtihad Vol. 12 No. 1 Juni 2018, h. 63.
} 
dengan jasa penyedia pinjaman non bank bermunculan di dunia digital. Pengguna cukup mengakses melalui gawai tanpa perlu tatap muka dan dana langsung cair dalam hitungan jam. ${ }^{84}$

Kenyataan praktis tersebut dan tanpa bertele-tele membuat jasa pinjaman uang secara online kini disukai. Dari balik kemudahan tersebut maka bermunculanlah berbagai masalah sehingga beberapa nasabah terjerat dalam bunga yang tinggi. Pada umumnya, penyedia dana pinjaman yang biasanya dizalimi atau dirugikan karena pengembalian dana yang mungkin tidak sesuai tempo yang disepakati atau adanya kemungkinan piutang tidak kembali dengan berbagai alasan. Namun dalam hal ini dinilai berbeda, justru dalam kenyataannya malah pengguna dana yang terzalimi dengan berbagai intimidasi, ancaman bunga berlipat dan kehormatan diri yang terinjak-injak. ${ }^{85}$

Maraknya korban yang terjerat dalam pinjaman online disebabkan sebagai berikut; pola pikir masyarakat yang cenderung instan mendapatkan dana, minimnya akurasi dalam memperhitungkan pengembalian dana, dan perilaku beberapa masyarakat yang sarat dengan kepentingan seperti melakukan pelunasan dengan mengakses aplikasi lainnya yang juga penyedia pinjaman online alias cara gali lobang tutup lobang. ${ }^{86}$ Beberapa trik digunakan oleh aplikasi pinjaman online dalam upaya mengembalikan dananya yaitu; membuat panik pengguna pinjaman, akses data pribadi yang ada di ponsel sebagai muslihat, dan aksi masif menjerat pengguna secara berkelanjutan atau bunga yang berlipat-lipat. ${ }^{87}$

Pandangan ulama mengenai sadd al zari'ah sebagai instrumen yang pantas dalam menetapkan hukum tidak untuk dipeerdebaikan, apakah boleh atau tidak menggunakan sadd al zari'ah. Dasar pengambilannya hanya semata-mata berlandaskan ijtihad yang berbasis tindakan hati-hati dalam beramal dan jangan sampai terjerumus dalam perbuatan yang dapat menimbulkan kerusakan. Keberadaan sadd al zari'ah tetap dinilai punya muatan yang sarat makna dalam menilai sesuatu yang baru. Adapun yang dijadikan patokan dalam tindakan adalah kehati-hatian yang merupakan faktor manfaat dan mudarat atau baik dan buruk. ${ }^{88}$ Dengan demikian, sebagian ulama ada yang menempatkan bahasannya dalam deretan dalil-dalil syara' yang tidak disepakati ulama tapi bukan berarti harus disingkirkan.

Penempatannya sebagai dalil dalam menetapkan hukum meskipun diperselisihkan penggunaannya tetap bermuatan syara' yang ketetapannya jelas mengenai hukum suatu perbuatan. Namun dengan adanya sebuah perbuatan yang terlarang secara jelas maka hal tersebut menjadi penunjuk atau dalil bahwa hukum wasilah itu sebagaimana hukum yang ditetapkan syara' terhadap perbuatan pokok. Perhatian ulama tentang sadd al zari'ah diadopsi dari beberapa akademisi Islam karena maraknya ayat-ayat yang mengisyaratkannya. Salah satu ayat dalam surah al-'an'am (6): 108:

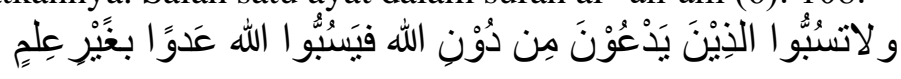

"Artinya: Janganlah kamu caci maki orang yang menyembah selain Allah karena nanti ia akan mencaci Allah dengan memusuhi tanpa sepengetahuan"

Tindakan mencaci maki dan menghina penyembah selain Allah SWT dinilai sah-sah saja, bahkan jika perlu dengan memeranginya. Namun tindakan mengumpat, mencaci maki, menghina berdampak pada perkara yang menggiring ke sesuatu yang dinilai buruk yaitu adanya balasan dari penyembah selain Allah dengan cara membalas cacian tersebut dengan tindakan yang serupa bahkan lebih parah sehingga perbuatan mencaci dan menghina menjadi dilarang.

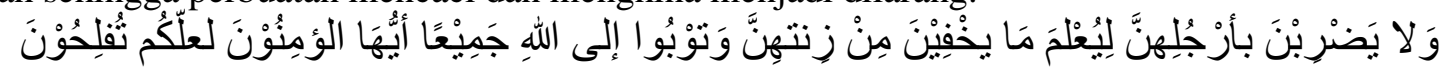

"Artinya: Janganlah perempuan itu menghentakkan kakinya supaya diketahui orang perhiasan yang tersembunyi di dalamnya"

\footnotetext{
${ }^{84}$ Junanto Herdiawan, Millenial Generation Outlook 2017, Makalah disampakian dalam Seminar sebagai Plt. Fintech Office Bank Indonesia pada tanggal 24 Februari 2017.

${ }^{85}$ Zilvia Iskandar, Jerat Pinjaman Online, diakses dari metrotv.com dan dipublikasikan dalam NSI Metro TV pada tanggal 18 Agustus 2018.

${ }^{86}$ Lihat, Eka Budiyanti, “Upaya Mengatasi Layanan Pinjaman Online Ilegal”, h. 20.

${ }^{87}$ Junanto Herdiawan, Millenial Generation Outlook 2017.

${ }^{88}$ Lihat, Amir Syarifuddin, Ushul Fiqh Jilid II, h. 429.
} 
Aksi menghentakkan kaki yang dilakukan perempuan adalah sesuatu yang normal atau biasabiasa saja, namun karena aksi perempuan tersebut berakibat pada perhiasan yang awalnya tersembunyi dapat diketahui orang sehingga akan menimbulkan rangsangan atau memancing bagi yang mendengarnya, maka menghentakkan kaki tersebut dinilai terlarang. ${ }^{89}$

Kedua ayat tersebut merefleksikan perkara lainnya yang dinilai up to date dan memungkinkan untuk mewakili berbagai perkara lainnya yang bersejalan dengan dinamika kehidupan manusia, baik itu ada teks, makna atau spiritnya. ${ }^{90}$ Perkara tersebut sudah termasuk dengan perkembangan jasa keuangan berbasis teknologi yang dinilai mubah namun karena ditujukan untuk perbuatan buruk atau modus kejahatan, baik sengaja atau tidak sengaja maka status hukum beralih staus menjadi terlarang. Fintech yang ada di era milenial diposisikan sama dengan perkara menghentakkan kaki atau mencaci maki sesembahan agama lain. ${ }^{91}$

Pada awalnya zari'ah berkategori mubah sebagaimana fintech yang ditujukan untuk kemaslahatan namun dalam keadaan tertentu beralih status menjadi terlarang dengan muatan kerusakan atau mafsadah (kerusakan) didalamnya. Fintech dengan jenis pinjaman online adalah perkara yang bebas nilai atau mubah namun karena diboncengi sesuatu buruk maka terindikasi jelas muslihat dan kerusakannya. Begitupun sebaliknya jika diboncengi dengan sesuatu bernilai baik (istislahi) maka peruntukannya didominasi dengan sesuatu maslahatnya lebih dominan.

Pinjaman online yang terdapat dalam bagian jasa keuangan berbasis teknologi dapat dialihkan hukumnya menjadi sadd al zari'ah dengan ketentuan bahwa pinjaman online terindikasi dan terbukti menjerat atau menjebak penggunanya dalam perihal sebagai berikut:

a. kesusahan (membuat panik pengguna, merasa diintimidasi);

b. kerusakan (akses data pribadi yang terekspose);

c. kehinaan (stigma yang berkelanjutan, menggerus kepercayaan dan bahkan berujung pada hilangnya pekerjaan seseorang).$^{92}$

Realitas layanan pinjaman online ilegal yang bertindak semena-mena dalam menerapkan bunga hutang dinilai cukup meresahkan. ${ }^{93}$ Pembahasan mengenai perbedaan pinjaman online dengan pinjaman konvensional disajikan pada Tabel $4 .{ }^{94}$

Tabel 4. Perbedaan Pinjaman Online dengan Pinjaman Konvensional

\begin{tabular}{cc}
\hline Pinjaman Konvensional & Pinjaman Online \\
\hline Suku bunga berkisar dari 0,99-2\% per tahun & Bunga mencapai 1,5\% per hari (14\% per tahun) \\
Ada pinalti bila telat bayar pinjaman & Terlambat membayar, pinalti setiap hari \\
Ada asuransi dan BI Checking & Tidak ada asuransi dan BI Checking \\
Minimal gaji sekitar 3 juta/bulan & Minimal gaji 1 juta/bulan \\
Tenor pinjaman hingga 5 tahun & Tenor pinjaman 6 bulan s/d 1 tahun \\
Plafon/besarnya dana mencapai 250 juta & Plafon/besarnya dana maksimal 10 juta \\
Proses berkisar antara 1-2 pekan & Proses berkisar kurang 1 minggu \\
Banyak dokumen yang harus disiapkan & Dokumen lebih sedikit \\
Memiliki kartu kredit minimal 1 tahun & Tidak wajib punya kartu kredit \\
\hline
\end{tabular}

Keterangan di atas menunjukkan bahwa adanya perbedaan yang kontras antara keduanya namun pinjaman online dinilai berpotensi meresahkan pengguna meskipun dengan keunggulan yang

${ }^{89}$ Lihat, Amir Syarifuddin, Ushul Fiqh Jilid II, h. 426.

${ }^{90}$ Lihat, Muhazzab Abu Ahmad, Nahwa Fiqhi Wa'in Sadd al Zari'ah, diakses dari https://saaid.net/aldawah/191.htm pada tanggal 4 Oktober 2019.

${ }^{91}$ Lihat, Amir Syarifuddin, Ushul Fiqh Jilid II, h. 427.

${ }^{92}$ Lihat, Zilvia Iskandar, Jerat Pinjaman Online, diakses dari metrotv.com dan dipublikasikan dalam NSI Metro TV atau youtube.com/metrotv pada tanggal 18 Agustus 2018.

${ }^{93}$ Tulus Abadi, Pinjaman Online Menjerat Maraknya Korban, sebagai Ketua Yayasan Lembaga Konsumen Indonesia YLKI diakses via medcom.id dan youtube,com/metrotv pada tanggal 21 September 2019.

${ }^{94}$ Tulus Abadi, Jerat Rentenir Online, sebagai Ketua YLKI dalam artikel via mediaindonesia.com atau youtube,com/metropagiprimetime diakses pada tanggal 13 September 2019. 
dimilikinya seperti tidak perlu ke bank, efisiensi waktu, penyederhanaan proses, akselerasi pencairan dan minimnya dokumen. Keunggulan yang dimiliki pinjaman online tersebut mendongkrak maraknya fintech ilegal lainnya. Kondisi tersebut dipertajam dengan perilaku, pola pikir dan pola hidup masyarakat yang tentunya memperlebar situasi krisis dan bukannya mempertajam pikiran kritis sehingga aduan konsumen bertambah semarak.

Ketua Satgas Waspada Investasi Otoritas Jasa Keuangan, Tongam Lumban Tobing menegaskan bahwa OJK membekukan 404 fintech ilegal dan berharap konsumen berhati-hati dalam memilih fintech dan tidak meminjam uang dengan bunga yang tidak wajar sebab keadaan tersebut yang memunculkan kasus penagihan yang disertai teror juga kebocoran data pribadi. Keadaan tersebut diamini Pengacara Publik LBH Jakarta Yenny Sirait yang menerima banyaknya aduan terkait fintech ilegal. ${ }^{95}$

Konsep sadd al zari'ah bisa beralih status menjadi fathu al zari'ah yang dinilai awalnya sarat dengan potensi kerusakannya namun menjadi dibolehkan dan diterima dengan pertimbangan ada kemaslahatan didalamnya sebagaimana melihat aurat pasien bagi dokter spesialis yang jelas secara teks Alquran melarang namun dengan pertimbangan kesembuhan dan kepentingan mendesak sehingga beralih status hukumnya menjadi dibolehkan. ${ }^{96}$

Keberadaan sadd al zari'ah dalam menghadapi pinjaman online lebih terkesan merenggangkan hubungan antar manusia daripada merekatkan, dinilai menjadi penyekat daripada perekat antar manusia karena fintech pinjaman online lebih banyak yang ilegal dengan jumlahnya lebih banyak daripada fintech pinjaman online yang mempunyai status hukum atau berizin dari lembaga otoritas jasa keuangan yang mempunyai wewenang pengawasan dan pembinaan.

Problematika jeratan pinjaman online lebih marak terjadi di masyarakat dengan berbagai aduan yang tercatat di satgas investasi OJK sehingga perlu direformulasi secara konkrit dan praktik, legal law dan jurisprudence law. Pengembanan sadd al zari'ah yang terdapat dalam literatur formulasi hukum Islam adalah pengembanan hukum teoritis dalam membangun ilmu hukum secara nasional. Dalam konteks hukum, pengembanan meliputi kegiatan membentuk, melaksanakan, menerapkan, menemukan, menafsirkan, meneliti, hingga mengajarkan hukum. Pengembanan hukum teoritikal yang terkristalisasi dalam bentuk sadd al zari'ah adalah kegiatan akal budi untuk memperoleh penguasaan intelektual atas hukum atau pemaknaan hukum secara ilmiah, yakni secara sistemik, logik dan rasional.

Eksistensi dari sadd al zari'ah dalam hukum Islam bertujuan mencerdaskan pola pikir dan pola hidup dengan menstimulus sebuah ekspektasi yang merealisasikan cita hukum. Konsep sadd al zari'ah adalah pengembanan hukum teoritikal yang lebih terbuka dengan tujuan membangun ilmu hukum yang hidup di kalangan publik. Kegiatan mewujudkan hukum dalam kenyataan fintech secara konkret dalam bentuk; pembentukan hukum, penemuan hukum dan bantuan hukum. ${ }^{97}$ Sumber sadd al zari'ah dikonstruksi dan ditemukenali karena muatannya adalah teologis, esoterik dan profetik sehingga relevan untuk diaktualisasikan di era modern.

Eksistensi sadd al zari'ah (upaya preventif) jika dielaborasi dengan cukup cermat maka akan menjelma sebagai perangkat yang mengantisipasi maraknya kejahatan dalam layanan keuangan berbasis teknologi. Financial technology di era modern adalah keniscayaan yang mesti terwujud karena kehidupan manusia sarat dengan perubahan. Fintech adalah sesuatu yang bebas nilai sehingga kehadirannya menjadi pilihan bagi pengguna atau penyedia jasa keuangan berbasis teknologi tersebut, apakah mengedepankan maslahat atau justru memunculkan ragam muslihat (tipu daya, manipulasi, intimidasi) yang berdampak pada menjerat dan menjebak pengguna dalam nestapa yang berkelanjutan. ${ }^{98}$

\footnotetext{
${ }^{95}$ Tongam Lumban Tobing, Fintech Ilegal Makin Nakal, keterangan sebagai Ketua Satgas Investasi OJK dalam acara profit di cnbcindonesia.com diakses 10 September 2019.

${ }^{96}$ Lihat, Wahab al Khallaf, 'Ilmu Usul al Fiqh (Cet. XII; Dimasq: Dar al Qalam, 1398 H), h. 81-82

${ }^{97}$ Lihat, Sidharta, "Menemukenali Pengembanan Hukum Teoritis", Digest Epistema Berkala Isu Hukum dan Keadilan Eko-Sosial Volume 5/2015, h. 17-20

${ }^{98}$ Lihat, Sulaiman, "Pengembanan Hukum Teoritis dalam Pembangunan Ilmu Hukum di Indonesia", Kanun Jurnal Ilmu Hukum No. 67 Tahun XVII/Desember 2015, h. 585-601.
} 
Dalam realitasnya, maraknya kejahatan dalam pinjaman online lebih didominasi oleh penyedia jasa pinjaman online. ${ }^{99}$ Terhitung 29 Juli 2019, maraknya pinjaman online telah disikapi oleh OJK dengan memblokir 1087 fintech ilegal meskipun telah ada kegiatan masif dan represif tersebut tidak serta merta menjamin drastisnya kasus yang ada di lapangan. ${ }^{100}$ Problem yang selalu terjadi biasanya seputar penagihan yang tidak beretika dan keberadaan bunga yang dinilai tinggi dan sangat meresahkan. ${ }^{101}$

Aktualisasi sadd al zari'ah dengan keberadaan maraknya fintech ilegal memungkinkan untuk dilakukan sebagai langkah preventif dan kuratif berkenaan dengan sosiologi masyarakat, legal law dan pemerintah atau stake holder. Langkah preventif dan kuratif yang perlu dilakukan berkenaan dengan sosiologi masyarakat sebagai berikut:

a. Kepastian hukum fintech pinjaman online dan izin operasionalnya seperti Otoritas Jasa Keuangan, Kemeninfo, Kementerian Keuangan, Yayasan Lembaga Perlindungan Konsumen dan stake holder lainnya;

b. Menempatkan posisi sebagai pengguna dengan kemampuan melunasi pinjaman dan bukan dengan melakukan gali lubang tutup lubang;

c. Optimalisasi mitigasi resiko dan bahayanya sebelum menentukan pilihan dalam mengambil keputusan. Pemahaman total berkenaan perjanjian didalamnya.

Adapun aktualisasi sadd al zari'ah yang berkenaan dengan hukum atau legal law adalah memastikan adanya payung hukum yang jelas seperti optimalisasi fokus terhadap perlindungan konsumen dan transparansi keuangan. ${ }^{102}$ Dalam ketentuan hukum di Indonesia bahwa pengguna pinjaman online tidak bisa dipidana karena ketidakmampuan melunasi kewajiban hutangnya. Ajaran Islam juga demikian, bahwa ketidakmampuan pengguna pinjaman untuk diberikan tenggang waktu yang memungkinkan adanya waktu tambahan sambil berusaha melunasi hutangnya.

Sedang aktualisasi sadd al zari'ah yang berkenaan dengan keberadaan pemerintah dan stake holder lainnya adalah sosialisasi masif dengan memperkuat dan mempertegas literasi keuangan, literasi teknologi, literasi baca dan literasi budaya. Pentingnya penguatan literasi teknologi bukan diartikan buta teknologi tetapi realitas masyarakat yang dinilai melek teknologi tetapi minim cerdas teknologinya. Begitupun dengan literasi keuangan yang dinilai hanya melek keuangan namun tidak cerdas keuangan karena pola gaya hidupnya masih dominan daripada kebutuhan hidupnya.

Keberadaan sadd al zari'ah dalam kajian dan perumusan hukum Islam merupakan pengembangan dari metodologi ijtihad untuk meretas dan mengantisipasi laju zaman yang sedemikian pesat dan aksi terobosan ilmiah dan aktual karena sadd al zari'ah sarat dengan prioritas maslahat dan mendisrupsi atau meminimalisir kerusakan dan muslihat. ${ }^{103}$

\section{SIMPULAN}

Kemajuan teknologi yang semakin pesat meniscayakan kemudahan akses aplikasi online dalam berbagai bidang termasuk pinjaman yang biasanya ditangani lembaga keuangan perbankan. Keberadaan jasa keuangan berbasis teknologi telah merambah ke berbagai dimensi kehidupan manusia dengan penyederhanaan proses, efisiensi dan efektifitas. Dengan skema tersebut, peminjam tidak perlu ada jaminan atau agunan namun dengan resiko besar, seperti startup berbasis fintech menarik bunga tinggi kepada peminjam atau nasabah. Tingginya bunga serta kurangnya mitigasi terhadap faktor resiko dianggap menjadi bom waktu.

\footnotetext{
${ }^{99}$ Wimboh Santoso, Jerat Maut Pinjaman Online, diakses dari cnnindonesia.com dan Channel CNN Indonesia di Trans Vision pada 31 Mei 2016.

${ }^{100}$ Tongam L. Tobing, Wimboh, Maraknya Pinjaman Online telah Diblokir oleh OJK sebanyak 1087 Fintech Ilegal, keterangan sebagai Ketua Satgas Waspada Investasi Otoritas Jasa Kuangan diaskes via youtube.com/newsprime/metro.tv dipublikasikan pada tanggal 29 Juli 2019.

${ }^{101}$ Wimboh Santoso, Jerat Maut Pinjaman Online, diakses dari cnnindonesia.com dan Channel CNN Indonesia di Trans Vision pada 31 Mei 2016.

${ }^{102}$ Fintech ilegal biasanya tidak memiliki alamat jelas dan aksi penagihan yang tidak beretika. Tongam

L. Tobing, Wimboh, Maraknya Pinjaman Online telah Diblokir oleh OJK sebanyak 1087 Fintech Ilegal.

${ }^{103}$ Lihat, Amir Syarifuddin \& Abdul Halim, Meretas Keebekuan Ijtihad, Isu-isu Penting Hukum Islam Kontemporer di Indonesia (Jakarta: Ciputat Press, 2005), h. 127
} 
Realitas maraknya fintech ilegal dengan kinerja nakalnya dinilai cukup meresahkan dan bahkan ada beberapa fintech legal yang ditengarai ikut bermain didalamnya. Fintech dengan sub sector "peer to peer lending" yaitu pinjam meminjam modal secara online menunjukkan lebih banyak bahaya dan membahayakan daripada aksi tolong menolongnya. Perlindungan pengguna dan transparansi keuangan menjadi kunci kepercayaan masyarakat sedang memarginalkan pengguna dan ketidakjujuran keuangan berakibat maraknya kasus dan korban.

Sadd al zari'ah adalah model pengembangan ijtihad yang memprioritaskan kehati-hatian dan dinilai menjadi instrumen yang mampu mengedukasi masyarakat luas sehingga tidak mudah terjerumus dalam ancaman bahaya dan membahayakan. Upaya memasifkan sadd al zari'ah sebagai pengembanan hukum teoritis dan praktis dalam Islam menjadi hukum yang aktual akan mewujudkan hukum yang konkret dalam bentuk; pembentukan hukum, penemuan hukum dan bantuan hukum. Aktualisasi sadd al zari'ah menjelma sebagai kegiatan akal budi untuk memperoleh penguasaan intelektual tentang hukum atau pemahaman sadd al zari'ah secara ilmiah.

\section{DAFTAR PUSTAKA}

Abadi, Tulus. Jerat Rentenir Online, sebagai Ketua YLKI dalam artikel via mediaindonesia.com atau youtube,com/metropagiprimetime diakses pada tanggal 13 September 2019.

, Tulus. Pinjaman Online Menjerat Maraknya Korban, sebagai Ketua Yayasan Lembaga Konsumen Indonesia YLKI diakses via medcom.id dan youtube,com/metrotv pada tanggal 21 September 2019.

Ahmad, Muhazzab Abu. Nahwa Fiqh Wa'in Sadd al Zari'ah, diaskes dari https://saaid.net/aldawah/191.htm pada tanggal 4 Oktober 2019.

Muhazzab Abu. Nahwa Fiqhi Wa'in Sadd al Zari'ah, diakses dari https://saaid.net/aldawah/191.htm pada tanggal 4 Oktober 2019.

Akmaluddin, Muhammad. "Pesan Profetik Lingkungan dalam Hadis", Jurnal Penelitian IAIN Pekalongan, Volume 14 Nomor 2 Tahun 2017.

Annur, Cindy Mutia. Dorong 1000 Startup Kominfo Siapkan Berbagai Program Inovasi, sambutan saat pertemuan The $1^{\text {st }}$ Next Indonesia Unicorn International Summt di Bali 9 Mei 2018 dan diakses via katadata.co.id pada tanggal 21 September 2019.

Cindy Mutia. Survey Asosiasi Penyelenggara Jasa Internet; Penetrasi Pengguna Internet di Indonesia Capai 64,8\%, diakses dari https://katadata.co.id/ pada tanggal 20 September 2019.

Anwar, Desi. Membangun Perekonomian Digital di Indonesia, dalam wawancara bersama Pendiri TANIHUB \& KOINWORKS di Insight CNN Indonesia dipublikasikan tanggal 9 Desember 2016.

Antara, Ngakan Timur \& Sonny Iskandar, Hot Economy, Strategi Revolusi Industri 4.0, keterangan ahli sebagai Wakil Ketua Umum KADIN, Sekretaris Jenderal APINDO dan Ketua Umum Himpunan Kawasan Industri Indonesia, diakses via beritasatu.tv dan dipublikasikan 6 April 2018.

Ariwibowo, Teguh. Jerat Pinjaman Online, diakses dari metrotv.com dan dipublikasikan dalam NSI Metro TV pada tanggal 6 Juni 2016.

Asmawi. Dimensi-dimensi Syari'ah Dari Teologi, Hukum, Akhlaq Sampai Sejarah Pemikiran. Tulungagung: STAIN Tulungagung Press, 2013.

A.P Kau, Sofyan. Metode Penelitian Hukum Islam Penuntun Praktis untuk Penulisan Skripsi dan Tesis (Cet. I; Gorontalo: Sultan Amai Press IAIN Gorontalo, 2009.

Anggraeni, Kartika. Transaksi e-commerce di Indonesia Tertinggi di Asia Tenggara, diakses via bisnis.tempo.co.id pada tanggal 30 September 2019.

Azhari, Fathurrahman. Qawa'id Fiqhiyyah Muamalah Cet. I; Banjarmasin: Lembaga Pemberdayaan Kualitas Umat, 2015.

Badan Pengembangan dan Pembinaan Bahasa. Kamus Besar Bahasa Indonesia Daring (Jakarta: Kemdikbud, 2016), diakses via online dari kbbi.kemdikbud.go.id

Bank Indonesia. Statistik Sistem Pembayaran, diakses bi.go.id pada tanggal 29 September 2019. Edukasi, diakses dari https://www.bi.go.id/id pada tanggal 22 September 2019. 
Budiyanti, Eka. "Upaya Mengatasi Layanan Pinjaman Online Ilegal”, Jakarta: Pusat Penelitian Badan Keahlian DPR RI Bidang Ekonomi dan Kajian Publik Info Singkat Kajian Singkat terhadap Isu Aktual dan Strategis Vol. XI No. 04/II/Puslit/Februari 2019.

Caksono. Jumlah Populasi Muslim Dunia, dirilis dari website Media Indonesia pada tanggal 12 September 2019.

Dalharmasaputro, Karania. Menakar Masa Depan Financial Technology, sebagai CEO Baraksa dalam liputan ekonomi finansial CNN Indonesia pada tanggal 25 September 2016.

Djalil, Abdul et. all., Fiqh Rakyat Pertautan Fiqh dengan Kekuasaan (Cet. II; Yogyakarta: LKiS Pelangi Aksara Yogyakarta, 2011.

Djamil, Fathurrahman. Filsafat Hukum Islam Jakarta: Logos Wacana Ilmu, 1997.

Daniel, Wahyu. Transaksi e-commerce RI 2018 Mencapai 77 T, Lompat $151 \%$, diakses via https://www.cnbcindonesia.com/ pada tanggal 1 Oktober 2019.

Djazuli. Kaidah-kaidah Fikih, Kaidah-kaidah Hukum Islam dalam Menyelesaikan Masalah-masalah yang Praktis. Cet. III; Jakarta: Kencana Prenada Media, 2010.

F. Haryn, Hera. Masa Depan Industri Keuangan, diakses dari cnnindonesia.com dan Channel CNN Indonesia di Trans Vision pada 31 Mei 2016.

al Fasi, Muhammad bin al Hasan al Hujwi al Tsa'labi. al Fikr al Sami fi Tarikh al Fiqhi al Islami. Cet. I; Beirut: Dar al Kutub al Ilmiyyah, 1995.

Hera. Masa Depan Industri Keuangan, diakses dari cnnindonesia.com dan Channel CNN Indonesia di Trans Vision pada 31 Mei 2016.

Fanani, Muhyar. Metode Studi Islam Aplikasi Sosiologi Pengetahuan sebagai Cara Pandang (Yogyakarta: Pustaka Pelajar, 2008.

Hariyanti, Iswi \& Cita Yustisia Serfiyanti, "Perlindungan Hukum dan Penyelesaian Sengketa Bisnis Jasa PM-TEKFIN"..

Iswi. \& Cita Yustisia Serfiyanti, "Perlindungan Hukum dan Penyelesaian Sengketa Bisnis Jasa PM-TEKFIN”, Jurnal Legislasi Indonesia Volume 14 No. 03 September 2017.

Haryono, Benedicto. \& Ivan Ari Sustiawan, Membangun Perekonomian Digital di Indonesia, keterangan sebagai Pendiri TANIHUB \& KOINWORKS di Insight CNN Indonesia dipublikasikan tanggal 9 Desember 2016.

Haroen, Nasrun. Ushul Fiqh I Jakarta: Logos Wacana Ilmu, 1997.

H. B. Syafuri. "Epistemologi Hukum Fatwa KUI Kabupaten Lebak tentang Berboncengan dengan Selain Muhrim", Jurnal Al Ahkam Volume XVI No. 2 Juli 2016.

Herdiawan, Junanto. Millenial Generation Outlook 2017, Makalah disampakian dalam Seminar sebagai Plt. Fintech Office Bank Indonesia pada tanggal 24 Februari 2017.

Idrus, Achmad Musyahid. Perkembangan Penalaran Filosofis dalam Hukum Islam. Cet. I; Makassar: Alauddin University Press, 2013.

Iskandar, Zilvia. Jerat Pinjaman Online, diakses dari metrotv.com dan dipublikasikan dalam NSI Metro TV pada tanggal 18 Agustus 2018.

Jenie, Izak. Dewan Pengurus Asosiasi Fintech Indonesia dengan Startup Ranking

Khallaf, Wahab. Masadir al Tasyri' al Islamiy Ma la Nassa Fihi, diterjemahkan oleh Abubakar dan Anwar Rasyidi dengan judul: Sumber-sumber Hukum Islam Cet. I; Bandung: Risalah, 1984.

, Wahab. 'Ilmu Usul al Fiqh Cet. XII; Dimasq: Dar al Qalam, 1398 H.

'Abdul al Wahab. Ilmu Usul al Fiqh. Cet. XII; al Qahirah: Dar al Ilmi, 1398 H.

Khoiruddin, Azaki "Sains Islam Berbasis Nalar Ayat-Ayat Semesta", Jurnal At Ta'dib Volume 12 Nomor 1 Tahun 2017.

Karania. Menakar Masa Depan Financial Technology, keterangan sebagai CEO Bareska di CNN Indonesia dipublikasikan 23 September 2016.

al Mudarris, Abdu al Karim Muhammad. 'Ulama'una fi Khidmati al Ilmi wa al Din. Cet. I; Maroko: t.t., 1983.

Martowardojo, Agus D.W. Financial Technology Office Bank Indonesia, sambutan sebagai Gubernur BI saat peresmian Kantor Fintech BI 14 November 2016. 
Mathar, Qasim. Membuka Jendela Langit. Makassar: Galesong Group, 2017.

M. Qasim Alquran Wilayah Ijtihadi yang Maha Luas, disarikan dari Opini Harian Pagi Fajar 21 September 2019.

Munawaroh, Hifdhatul. "Sadd al Zari'ah dan Aplikasinya pada Permasalahan Fikih Kontemporer", Jurnal Ijtihad Vol. 12 No. 1 Juni 2018.

Misbahuddin. Ushul Fiqh; Studi Kaidah Lughawiyah, Kedudukan Hukum, Prioritas dan Pengembangannya Makassar: Alauddin Press, 2014.

Mahrus, Moh. Aplikasi al Zari'ah dan al Hilah dalam Perspektif Hukum Islam, diakses medianeliti.com pada tanggal 12 September 2019.

Nurhaida. Peluang Fintech di Indonesia, sebagai Wakil Ketua Otoritas Jasa Keuangan OJK dalam acara Tech News CNN Indonesia.

Putro, Widodo Dwi. \& Herlambang P Wiratraman, "Penelitian Hukum, antara Normatif dan Empiris", Digest Epistema Isu Hukun dan Keadilan Eko-Sosial Volume 5/2015.

Passagi, Hendrikus. Membangun Perekonomian Digital di Indonesia, keterangan sebagai Dirjen Pengawasan Fintech OJK, dipublikasikan 4 November 2017 di CNN Indonesia TV.

al Qatthan, Manna'. Tarikh Tasyri' al Islamiy, al Tasyri' wa al Fiqh. Riyadh: Maktabah al Ma'arif, $1422 \mathrm{H}$.

al Qayyim, Imam Ibnu. I'lam al Muwaqqi'in III . al Qahirah: Dar al Risalah, t.th.

Rusli, Nasrun. Konsep Ijtihad al Syaukani Jakarta: Logos Wacana Ilmu, 1999.

Raghuwanshi, Kailash. Pakar Startup dalam wawancara saat acara Property of CNBC Indonesia.

Rasyid, Abdul. Sekilas Perkembangan Fintech di Indonesia, artikel diakses dari https://businesslaw.binus.ac.id pada tanggal 12 September 2019.

Rahma, Inayah Aulia. et. all., "Peran Fintech dalam Meningkatkan Keuangan Inklusif pada UMKM di Indonesia", Masharif al Syariah Jurnal Ekonomi dan Perbanan Syariah Vol. III No. 1 Tahun 2018.

Samosir, Sondang Martha et.all., Menjamin Keamanan FinTech, Jakarta: Majalah Otoritas Jasa Keuangan Edukasi Konsumen Edisi Desember 2017.

Sidharta. "Menemukenali Pengembanan Hukum Teoritis", Digest Epistema Berkala Isu Hukum dan Keadilan Eko-Sosial Volume 5/2015.

Sulaiman. "Pengembanan Hukum Teoritis dalam Pembangunan Ilmu Hukum di Indonesia", Kanun Jurnal Ilmu Hukum No. 67 Tahun XVII/Desember 2015.

Sari, Fernika. Hati-hati, Fintech Ilegal Terus Berkeliaran Cari Korban, diakses via kontan.co.id pada tanggal 21 September 2019.

Saleng, Agus Tiar. Tantangan dan Peluang Revolusi Industri 4.0, Opini Harian Fajar tanggal 24 Juli 2019.

Salsabila, Putri. Dukung UKM Kreatif, MOKA Luncurkan Forum Edukasi ACOM, diakses via ekonomi.bisnis.com pada tanggal 12 Agustus 2019.

Santoso, Wimboh. Jerat Maut Pinjaman Online, diakses dari cnnindonesia.com dan Channel CNN Indonesia di Trans Vision pada 31 Mei 2016.

, Wimboh. Jumlah Fintech Ilegal Semakin Semarak, Kepala Otoritas Jasa Keuangan dalam Kabar Pasar TV One, Juli 2019.

Suleiman, Ajisatria. Masa Depan Industri Keuangan Digital, sebagai Direktur Eksekutif Asosiasi Fintech Indonesia dalam acara Property of CNN Indonesia.

Syarifuddin, Amir. \& Abdul Halim, Meretas Keebekuan Ijtihad, Isu-isu Penting Hukum Islam Kontemporer di Indonesia (Jakarta: Ciputat Press, 2005.

Amir. Ushul Fiqh II. Cet. V; Jakarta: Logos Wacana Ilmu, 2009.

as Siba'i, Musthafa Husni. Min Rawaa'i Hadaratina, diterjemahkan oleh Abdullah Zakiy al Kaaf dengan judul: Khazanah Peradaban Islam. Cet. I; Bandung: Pustaka Setia, 2002.

Thahir, A. Halil. Ijtihad Maqasidi, Rekonstruksi Hukum Islam Berbasis Interkoneksitas Maslahah. Cet. I; Yogyakarta: LKiS Printing cemerlang, 2015. 
Topindonesia. Indonesia Startup Ranking, diakses via https://www.startupranking.com/top/indonesia pada tanggal 21 September 2019.

Tobing, Tongam Lumban. Daftar Nama 143 Fintech Ilegal, sebagai Satgas Waspada Investigasi dan diakses via cnbcIndonesia.com.

, Tongam Lumban. Waspada Fintech Ilegal, sebagai Ketua Satgas Waspada Investasi dalam wawancara eksklusif TV One yang dipublikasi pada 18 Juli 2019 .

Tongam Lumban. Maraknya Pinjaman Online telah Diblokir oleh OJK sebanyak 1087 Fintech Ilegal, keterangan sebagai Ketua Satgas Waspada Investasi Otoritas Jasa Kuangan diaskes via youtube.com/newsprime/metro.tv dipublikasikan pada tanggal 29 Juli 2019.

,Tongam Lumban. Daftar 123 Fintech Ilegal Temuan Baru Satgas Waspada Investasi, diakses https://www.cnbcindonesia.com/ pada tanggal 30 September 2019.

Umar, Mukhsin Nyak. Kaidah Fiqhiyyah dan Pembaharuan Hukum Islam (Cet. II; Banda Aceh: Yayasan WDC Banda Aceh, 2017.

Umah, Anisatul. Merger OVO -DANA, Siasat Grab Jegal Gojek, liputan Closing Bell CNBC Indonesia dipublikasikan 12 September 2019 atau diakses via cnbc.indonesia.com/tech pada tanggal 24 September 2019.

Wiratmaja, Aline. Dilema Startup Bakar Uang, dibahas dalam Program Profit CNBC Indonesia pada 14 Maret 2019.

Yasid, Abu. Islam Moderat.Jakarta: Erlangga, 2018.

Zahrah, Muhammad Abu. Usul Fiqh Cairo: Dar al Fikr al Arabiy, t.th.

Zainuddin, Ahmad. Proyeksi 2019 Menyambut Kejutan-kejutan Dunia Fintech, diakses via https://tirto.id pada tanggal 10 September 2019.

Zaidan, Abdul Karim. al Wajiz fi Usul al Fiqh Beirut: Muassasah al Risalah, 1987.

Zain, Muhammad. Era Baru Pendidikan Tinggi, Belajar dari Hong Kong, Orasi Ilmiah Pembukaan Kuliah Akademik 2013-2014 STAIN Palopo, 9 September 2013. 